\title{
Hematological Values of 163 Normal Fetuses between 18 and 30 Weeks of Gestation
}

\author{
FRANÇOIS FORESTIER, FERNAND DAFFOS, FRÉDÉRIC GALACTÉROS, JOSIANE BARDAKJIAN, \\ MARTINE RAINAUT, AND YVES BEUZARD \\ Centre de Diagnostic Prénatal et de Foetologie, Hôpital Notre Dame de Bon-Secours, 66 Rue des Plantes 75014 \\ Paris [F.F., F.D., M.R.]; and INSERM U.91 et Laboratoire de Biochimie, Hôpital Henri Mondor 94010 \\ Creteil, France [F.G., J.B., Y.B.]
}

\begin{abstract}
Utilizing an easy and safe procedure for fetal blood sampling in utero we have studied 409 fetuses for prenatal diagnosis of rubella, toxoplasmosis, hemophilia, and hemoglobinopathies. Retrospectively we selected 163 fetuses confirmed as normal at birth and tested between 18 and 30 wk of gestation to establish normal hematological parameters and to follow the evolution of erythropoiesis, differential counts, hemoglobin synthesis, and hemostasis. Total white blood cell and platelet counts did not change during this period. The lymphocytes represented the main population and we observed a decrease of normoblasts during gestation. The results show a progressive increase of red blood cells and hemoglobin. This evolution is demonstrated by the ratio hemoglobin $A$ to acetylated hemoglobin F. No significant modification of hemostasis was observed over a 12-wk intrauterine gestation. These results provide useful reference values for future investigations. (Pediatr Res 20: 342-346, 1986)
\end{abstract}

\section{Abbreviations}

WBC, white blood cell count

$\mathrm{RBC}$, red blood cell count

PLT, platelet count

$\mathrm{Hb}$, hemoglobin

Ht, hematocrit

MCV, mean corpuscular volume

MCH, mean corpuscular $\mathrm{Hb}$

MCHC, mean corpuscular $\mathrm{Hb}$ concentration

RDW, red cell distribution width

IEF, isoelectrofocusing

Our knowledge of fetal hematology is limited due to the fact that most earlier studies were performed on aborted fetuses or under sampling conditions which may have altered hematological values. Moreover, only a few hematological values during gestation have been published (1). Having developed an easy and safe technique for fetal blood sampling, we selected retrospectively for this study 163 fetuses born healthy at full term delivery to establish reference fetal hematological values using standardized methods. To date no fetal loss or premature labor has been attributed to these fetal samplings.

Received June 24. 1985; accepted December 12, 1985.

Correspondence Dr. F. Forestier, Centre de Diagnostic Prénatal et de Foetologie Hôpital Notre Dame de Bon-Secours, 75674 Paris Cedex 14, France.

This work has been supported in part by grant from the Caisse Nationale de l'Assurance Maladie CNAMTS no. 618.

\section{MATERIALS AND METHODS}

Sampling procedure. The fetal sampling method has been described in detail previously $(2,3)$. A real time ultrasound scanner (ATL MARK III) was used to locate the umbilical cord insertion on the placenta and to determine the best route of access to it without fetal interposition. The transducer was then maintained immobile while, under aseptic conditions, local anesthesia was performed with $1 \%$ xylocaine into the anterior abdominal wall at the chosen puncture site. No $\beta$-mimetic drugs or other medication were used prior to the procedure. A 20-gauge spinal needle (10 or $13 \mathrm{~cm}$ long), filled with $0.129 \mathrm{M}$ sodium citrate solution and fixed to a $2 \mathrm{ml}$ disposable syringe containing $0.1 \mathrm{ml}$ of this solution, was introduced into the plane of the ultrasound sector near the transducer. The needle tip emitted a clearly visible echo and its progress toward the insertion of the cord was followed on the scope. The vein of the cord was punctured about $1 \mathrm{~cm}$ from its insertion.

Immediately after the first drop of blood was obtained, the syringe was replaced by a new one containing no additive. The blood sample was immediately transferred into special tubes containing adequate anticoagulant for biological studies. The duration of the entire procedure was less than 10 min in $90 \%$ of the cases, and the automated evaluations of hematological parameters were completed within $30 \mathrm{~min}$.

Patients. We studied 409 pregnancies and 435 fetal blood samplings were carried out (26 repetitive samplings) with the approval of the ethics committee of the hospital, the medical expert panel, and the informed consent of the patients. The fetal samplings were conducted for the prenatal diagnosis of toxoplasmosis (285 cases), rubella (37 cases), or hemophilia (30 cases), for rapid fetal karyotyping ( 32 cases), or for diagnosis of other miscellaneous conditions ( 25 cases). Medical abortions of affected fetuses were performed in 51 cases. For this study, aimed at establishing hematological reference values, we obtained data from 163 fetuses born in good health at full term delivery, without intrauterine growth retardation, and sampled between 18 and $30 \mathrm{wk}$ of gestation. Hematological data also were obtained from 63 mothers at the date of the fetal blood sampling; these women were selected because of the absence of iron and folate deficiencies. Their corresponding neonates also were studied (the cord blood was collected at delivery by direct puncture under aseptic conditions).

Biological investigations. Usually we obtained approximately $2 \mathrm{ml}$ of blood and divided it into three aliquots: about $500 \mu \mathrm{l}$ anticoagulated in lyophilised EDTA $\mathrm{K}_{2}$ from Sarstedt (ref. 32332 ); $400 \mu \mathrm{l}$ collected in $0.129 \mathrm{M}$ sodium citrate solution in an Eppendorf microtube (ref. 72698), ratio 9/1; and about 500 $\mu \mathrm{l}$ drawn into a heparin-lithium dry mixture. The remaining blood was not anticoagulated. Hematological parameters were determined with a Coulter Counter S Plus II. 
The following parameters were measured in the hospital laboratory immediately after the sampling: WBC, RBC, PLT, Hb, $\mathrm{Ht}, \mathrm{MCV}, \mathrm{MCH}, \mathrm{MCHC}$, and RDW. The histograms of the volumes of WBC, RBC, and PLT were recorded. The blood smears were stained with the May Grunwald Giemsa method for the differential blood count. From these data and the white cell counts provided by the Coulter, the number of nucleated red cells was determined. The Kleihauer Betke test (4), used to confirm the absence of contamination by maternal blood, was done using the fetal $\mathrm{Hb}$ test from Boehringer.

Biochemical measurements. Hb samples consisted of $0.2-0.5$ $\mathrm{ml}$ of EDTA anticoagulated fetal blood. Standard procedures were used for $\mathrm{Hb}$ studies as described by Basset et al. (5). The tests used included I.E.F., citrate agar electrophoresis, and scanning of the gels with a densitometer (Cello-System, Sebia, France). The results provided information about the expression of adult $\mathrm{Hb}$ related to gestational age and the frequency of $\mathrm{Hb} \mathrm{F}$ Sardinia ( $\gamma 75$ Thr-136 Ala).
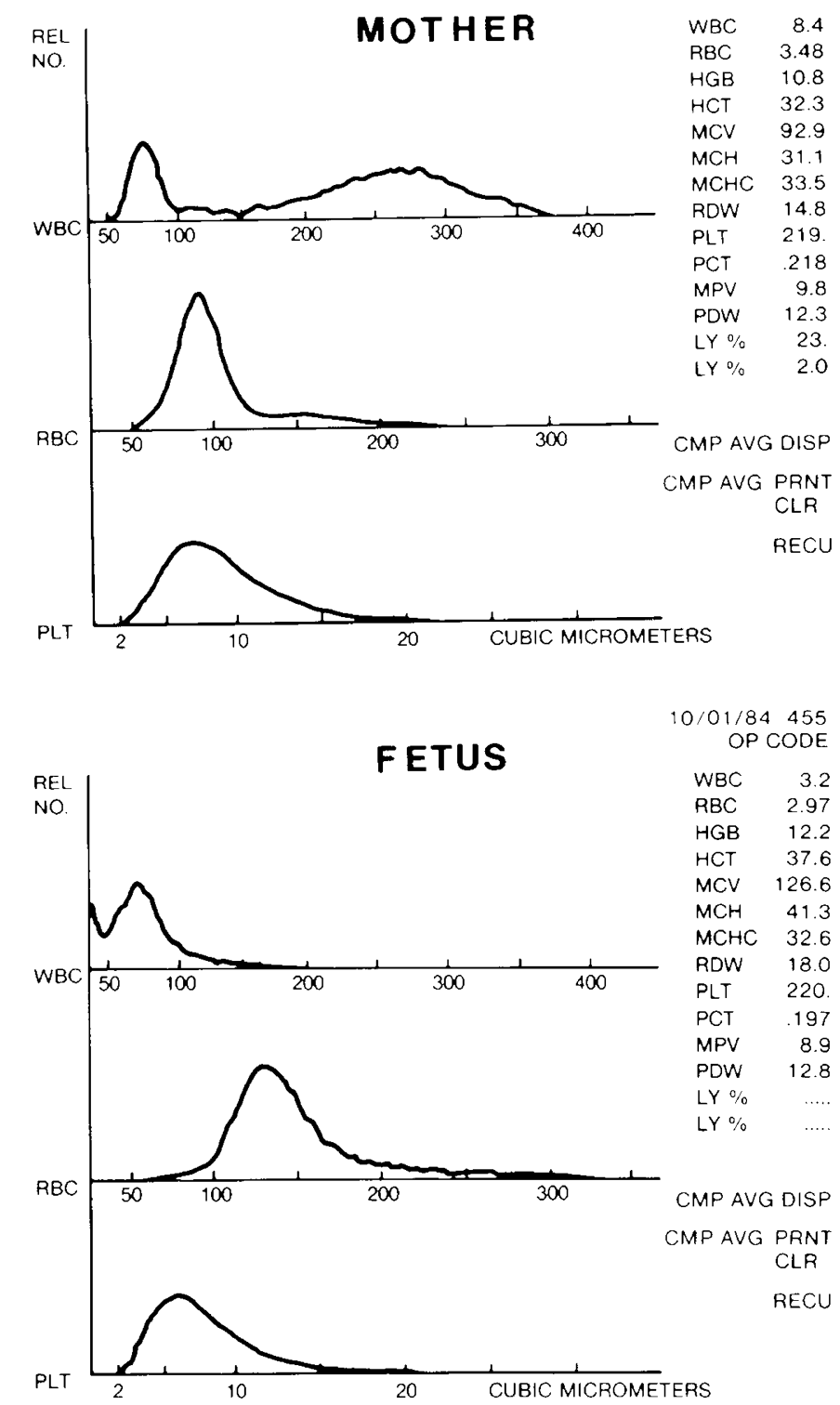

Fig. 1. Graphics terminal which displays histograms of white cell, red cell, and platelet distribution curves of a mother and her related fetus.
Ferritin was measured in 14 cases using a radioimmunoassay kit (Ferk-CEA, France).

Coagulation tests were performed on 103 frozen plasmas with a single stage method for antihemophilic A and B factors, proaccelerin, prothrombin using KC 10 Dade (AHS). Factor VIII and IX's related antigen activities were measured by ELISA (Stago) and adapted on an Olli C $+\mathrm{D}$ (Kone-Westinghouse). All the factor VIII activities were compared to the WHO's reference plasma $80 / 511(6)$.

\section{RESULTS}

Typical distribution curves for $\mathrm{WBC}, \mathrm{RBC}$, and PLT volumes are presented in Figure 1 for a mother and her fetus at 20 wk of gestation. Only one peak of WBC is observed in the fetal histogram. The mean and SD of the main hematological parameters are summarized for 63 fetuses in Table 1 and compared with the data of 63 newborns (cord samples at birth) and their mothers. The fetal values were obtained at $22-23 \mathrm{wk}$ of gestation. The fetal WBC is low compared to adults $\left(3.92 / 8.76 \times 10^{9} /\right.$ liter; the PLT level is within the normal range and was never below 150 $\times 10^{9}$ /liter; the $\mathrm{RBC}$ count is $3.04 \pm 0.07 \times 10^{12} /$ liter with a high mean MCV $(125.4 \pm 1.2 \mathrm{Fl})$. The hematocrit is $37.9 \pm$ $0.7 \%$ and the $\mathrm{Hb} 12.4 \pm 0.24 \mathrm{~g} / 100 \mathrm{ml}$.

In order to better assess the evolution of the hematological parameters, we selected 163 fetuses confirmed retrospectively as normal at birth. Hematological values from 18 to $30 \mathrm{wk}$ of gestation are presented in Table 2.

We observed a gradual decrease of the MCV and an increase of the hematocrit. Total WBC counts did not change during this period, nor did the platelet counts. The increase of RBC is not substantial ranging from 2.66 to $3.52 \times 10^{12} /$ liter.

Linear regression analysis between $\mathrm{MCV}, \mathrm{MCH}, \mathrm{RBC}, \mathrm{RDW}$, $\mathrm{Ht}, \mathrm{Hb}, \mathrm{WBC}, \mathrm{PLT}$, or MCHC and gestational age were determined by least squared fitting. Significant correlations were observed between $\mathrm{MCV}, \mathrm{MCH}, \mathrm{RBC}, \mathrm{RDW}, \mathrm{Ht}$, and $\mathrm{Hb}$ versus the weeks of gestation as shown in Figure 2. No correlation was found between WBC, PLT, and MCHC versus gestation age.

Differential counts are summarized in Table 3 . Because acidophilic normoblasts are present in a normal fetal differential and because nuclei of normoblasts are counted as WBC by the Coulter, we thought it was relevant to record their presence in the differential count among 200 cells. The lymphocytes represent the main population and, during gestation, there is a progressive decrease in normoblastic cells from $12 \pm 8$ to $4 \pm 3.5 \%$.

Coagulation factors from 103 fetuses are summarized in Table

Table 1. Principal hematological data of 63 blood samples collected from fetuses between 22 and 23 wk of gestation compared to the data of 63 cord blood samples at birth and the corresponding mothers the day of the fetal blood sampling (mean $\pm S D$ )

\begin{tabular}{lccc}
\hline & $\begin{array}{c}\text { Fetuses }(22- \\
23 \mathrm{wk})\end{array}$ & $\begin{array}{c}\text { New borns } \\
\text { (cord samples } \\
\text { at delivery) }\end{array}$ & $\begin{array}{c}\text { Relative mothers } \\
\text { at the day of the } \\
\text { blood sampling }\end{array}$ \\
\hline WBC $\left(\times 10^{9} /\right.$ liter $)$ & $3.92 \pm 0.17$ & $11.11 \pm 4.42$ & $8.76 \pm 0.48$ \\
$\mathrm{RBC}\left(\times 10^{12} / \mathrm{liter}\right)$ & $3.04 \pm 0.07$ & $3.56 \pm 0.76$ & $3.86 \pm 0.05$ \\
$\mathrm{Hb}(\mathrm{g} / 100 \mathrm{ml})$ & $12.4 \pm 0.24$ & $13.29 \pm 1.6$ & $12.1 \pm 0.17$ \\
$\mathrm{Ht}(\%)$ & $37.9 \pm 0.7$ & $41.2 \pm 6.02$ & $36 \pm 0.5$ \\
$\mathrm{MCV}(\mathrm{F} 1)$ & $125.4 \pm 1.2$ & $118.81 \pm 14$ & $93.9 \pm 0.8$ \\
$\mathrm{MCH}(\mathrm{pg})$ & $41 \pm 2.27$ & $38.25 \pm 9.83$ & $31 \pm 0.1$ \\
$\mathrm{MCHC}(\mathrm{g} / 100 \mathrm{ml})$ & $32.8 \pm 1.65$ & $34.99 \pm 11.4$ & $33.6 \pm 0.2$ \\
Red cell distribution & $19.4 \pm 1.86$ & $20.53 \pm 1.4$ & $13.6 \pm 0.8$ \\
$\quad$ width & & & \\
Platelets $\left(\times 10^{9} / \mathrm{li}-\right.$ & $241 \pm 8$ & $299.5 \pm 58.4$ & $244 \pm 10$ \\
$\quad$ ter $)$ & & & \\
\hline
\end{tabular}


Table 2. Evolution of hematological values of 163 normal fetuses during pregnancy (mean \pm SD) from studies performed with a Coulter model S-PLUS II

\begin{tabular}{|c|c|c|c|c|c|c|c|c|c|}
\hline $\begin{array}{c}\text { Wk of } \\
\text { gestation }\end{array}$ & $\begin{array}{l}\text { WBC }(\times \\
\left.10^{9} / \text { liter }\right)\end{array}$ & $\begin{array}{l}\text { Platelets } \\
\left(10^{9} / \text { liter }\right)\end{array}$ & $\begin{array}{c}\mathrm{RBC}(\times \\
\left.10^{12} / \text { liter }\right) \\
\end{array}$ & $\begin{array}{c}\mathrm{Hb}(\mathrm{g} / 100 \\
\mathrm{ml})\end{array}$ & $\mathrm{Ht}(\%)$ & $\operatorname{MCV}(\mathrm{F} 1)$ & $\mathrm{MCH}(\mathrm{pg})$ & $\begin{array}{c}\text { MPHC (g/ } \\
100 \mathrm{ml})\end{array}$ & $\begin{array}{l}\text { Red cell } \\
\text { distribution } \\
\text { width }\end{array}$ \\
\hline $\begin{array}{l}18-20 \\
(n=25)\end{array}$ & $4.20 \pm 0.83$ & $242.1 \pm 34.48$ & $2.66 \pm 0.29$ & $11.47 \pm 0.78$ & $35.86 \pm 3.29$ & $133.92 \pm 8.83$ & $43.14 \pm 2.71$ & $32 \pm 2.38$ & $20.64 \pm 2.28$ \\
\hline $\begin{array}{l}21-22 \\
(n=55)\end{array}$ & $4.19 \pm 0.84$ & $258.2 \pm 53.65$ & $2.96 \pm 0.26$ & $12.28 \pm 0.89$ & $38.53 \pm 3.21$ & $130.06 \pm 6.17$ & $41.39 \pm 3.32$ & $31.73 \pm 2.78$ & $20.15 \pm 1.92$ \\
\hline $\begin{array}{l}26-30 \\
(n=22)\end{array}$ & $4.44 \pm 0.85$ & $253.54 \pm 36.6$ & $3.52 \pm 0.32$ & $13.35 \pm 1.17$ & $41.54 \pm 3.31$ & $118.17 \pm 5.75$ & $37.94 \pm 3.67$ & $32.15 \pm 3.55$ & $18.35 \pm 1.67$ \\
\hline
\end{tabular}
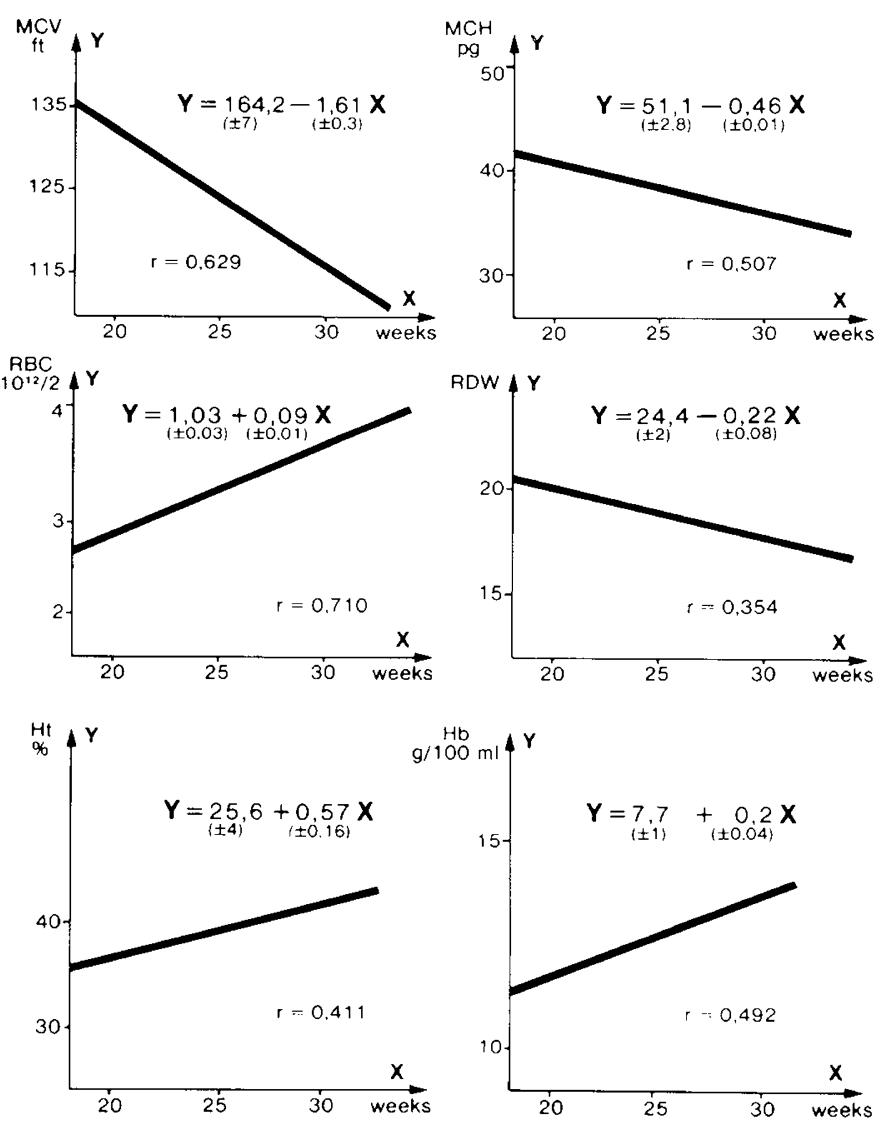

Fig. 2. Relationships between $\mathrm{RBC}, \mathrm{Hb}, \mathrm{Ht}, \mathrm{RDW}, \mathrm{MCV}, \mathrm{MCH}$ values and the gestational age of 163 normal fetuses by means of regression linear analysis.

4: antihemophilic A (coagulant and antigen related activities), antihemophilic B, proaccelerin $\mathrm{V}$, and prothrombin II. The mean value for factor VIIIC was $40 \%$ and for factor IX $9 \%$ between 19 and 21 wk. Mean factor $\mathrm{V}$ and II levels were respectively 39 and $13 \%$, and VIIIRAg 59\%. These values remained essentially unchanged through $27 \mathrm{wk}$. Means and SD values for pregnant women the day of the samplings were: VIIIC $160 \pm 80 \%$, VIIIRAg $190 \pm 110 \%$, IX $90 \pm 20 \%$, V $85 \pm 10 \%$, and II $95 \pm$ $15 \%$.

Repetitive samplings were carried out on five pregnant women with the aim of examining the evolution of selected enzyme activities and myoglobin values relating to a possible prenatal diagnosis of muscular dystrophy. Figure 3 illustrates the evolution of the RBC and the MCV values for the five fetuses each sampled three times or more during gestation. The results show a progressive increase of $\mathrm{RBC}$ in all the fetuses in good correlation with our normal hematological values during gestation (see Table 1 and Table 2).

Hb type was characterized in 125 samples: 45 (36\%) individuals had carried a fraction of fetal $\mathrm{Hb}$ with the IEF pattern of Hb F Sardinia ( $\gamma 75 \mathrm{Thr}-136$ Ala) (7); samples with a different chain mutation have been detected. In the complete group, no $\alpha$ variant was found, two cases of sickle cell trait and one case of $\mathrm{Hb} \mathrm{E}$ were noted. Hb Bart's was suggested in 13 cases, but clearly seen in nine. Unfortunately, sample volumes were too small to allow precise quantitation. In only one case, $\mathrm{Hb}$ Bart's elevation was accompanied by a microcytosis as defined in Table 2 . Table 5 shows the ratio of $\mathrm{Hb} \mathrm{A}$ to acetylated $\mathrm{Hb} \mathrm{F}(\mathrm{Hb} \mathrm{A} / \mathrm{Hb} \mathrm{Fac})$ as a function of the gestational age. Acetylated $\mathrm{Hb} F$ is a constant fraction of total $\mathrm{Hb} \mathrm{F}$ and represents about $8 \%$ of $\mathrm{Hb} \mathrm{F}$. These values, although overlapping, are proportional to gestational age with the following formula: $\mathrm{y}=0.019 \mathrm{x}+0.47(r=0.4)(\mathrm{y}=\mathrm{Hb}$ $\mathrm{A} / \mathrm{Hb}$ Fac ratio; $\mathrm{x}=$ gestational age in weeks). In two cases of suspected $\beta$-thalassemia trait, $\mathrm{Hb} \mathrm{A} / \mathrm{Hb} \mathrm{Fac}$ ratios were found to be low for the gestational age ( $20 \mathrm{wk}$ of gestation-ratio $0.45,22$ wk of gestation-ratio 0.2). In one case, we found a low level of $\mathrm{Hb} \mathrm{Fac}$, as compared with a normal $\mathrm{Hb} \mathrm{A}$ fraction for gestational age. Gamma chain variants had a high $\mathrm{Hb} \mathrm{A} / \mathrm{Hb}$ Fac ratio.

Ferritin values measured in 14 cases were between 19 and 98 $\mu \mathrm{g} /$ liter (mean $\pm \mathrm{SD}: 51.07 \pm 19.64$; wk of gestation: $23.5 \pm 4$ ).

\section{DISCUSSION}

For the present study we utilized a Coulter S Plus II, a very accurate instrument and well adapted to small volumes of blood and rapid identification of fetal blood by analysis of WBC and $\mathrm{RBC}$ volumes. Fetal bone marrow erythropoiesis begins between the 16th and 18th wk of gestation (8) as liver hematopoiesis (9) is challenged by hepatocyte proliferation (10-13). It has been noted that the changes in the number of circulating normoblasts between 10 and $18 \mathrm{wk}$ is associated with a progressive maturation of these cells (10). There is a diminution of the diameter and densification of the nucleus and more acidophilia. In our study, the number of late normoblasts markedly decreased (from $13 \pm$ 6 to $5 \pm 4 \%$ ) during the 12 -wk period of gestation studied. Our values are lower than previously reported (14). The normoblasts had almost the same cytological feature throughout this period. In contrast, changes in $\mathrm{RBC}$ and $\mathrm{Hb}$ levels were rather small. Maturation is demonstrated by a diminution of MCV and RDW, and by the moderate increase in $\mathrm{Hb} \mathrm{A}$ synthesis. Adult $\mathrm{Hb}$ is sufficiently separated from either $\mathrm{Hb} F$ or acetylated $\mathrm{Hb} F$ by IEF (15). Since acetylated $\mathrm{Hb} F$ is a constant fraction of $\mathrm{Hb} \mathrm{F}$ $(16,17)$, it is justified to follow the increase in $\mathrm{Hb} \mathrm{A}$ synthesis by the $\mathrm{Hb} \mathrm{A} / \mathrm{Hb} \mathrm{F}$ acetylated ratio (18) using IEF and gel scanning. 
Table 3. Some aspects of fetal differential counts from 18 to 30 wk of gestation of 163 normal fetuses (mean \pm SD)

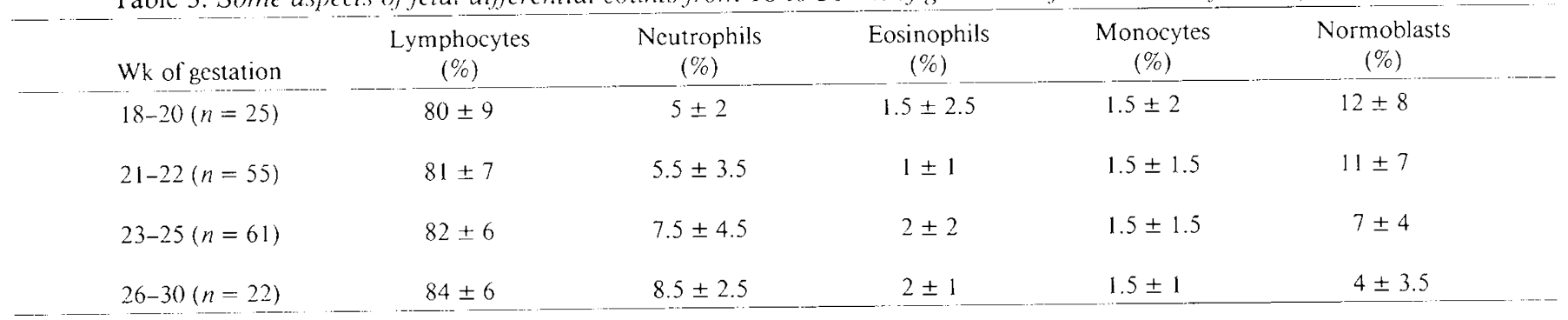

Table 4. Evolution of coagulation factors of 103 normal fetuses during pregnancy and their relative mothers (mean $\pm S D$ )

\begin{tabular}{|c|c|c|c|c|c|}
\hline $\begin{array}{c}\text { Fetuses } \\
\text { (wk of } \\
\text { gestation) }\end{array}$ & VIII C $(\%)$ & $\begin{array}{c}\text { VIII RAg } \\
(\%)\end{array}$ & $\begin{array}{l}\text { IX C } \\
(\%)\end{array}$ & V C $(\%)$ & II C $(\%)$ \\
\hline $\begin{array}{l}19-21 \\
(n=51)\end{array}$ & $40 \pm 12$ & $59 \pm 12.5$ & $9 \pm 2.5$ & $39 \pm 11$ & $13 \pm 4$ \\
\hline $\begin{array}{l}22-24 \\
(n=44)\end{array}$ & $39 \pm 13.5$ & $64 \pm 13$ & $9 \pm 3$ & $40.5 \pm 5$ & $14 \pm 2$ \\
\hline $\begin{array}{l}25-27 \\
(n=44)\end{array}$ & $42.5 \pm 12$ & $63 \pm 13$ & $12 \pm 4$ & $39 \pm 9$ & $14 \pm 3.5$ \\
\hline Mothers & $160 \pm 80$ & $190 \pm 110$ & $90 \pm 20$ & $85 \pm 10$ & $95 \pm 15$ \\
\hline
\end{tabular}

No cytological or quantitative changes were observed in platelets during the fetal period studied. This may indicate that mature megakaryocytopoiesis is completed before $18 \mathrm{wk}$ and before bone marrow erythropoiesis has begun (19). Interestingly, PLT were never below $150 \times 10^{9} /$ liter in normal fetuses. Neutrophils were very low and increased slightly from about 0.2 (20th wk) to 0.4 $\times 10^{9} /$ liter (30th wk). This pattern also is obvious in cases sequentially sampled and contrasts with the neutrophilia observed at birth. About half of the granulocytes are band forms throughout the studied period. This neutropenia also appears in the WBC volume distribution curve (Fig. 1).

It can be interpreted either as a strong margination or, more likely, as the physiological initiation of granulopoiesis in the bone marrow (19). Anatomophysiological data $(8,20)$ support the latter hypothesis. This observation also further supports the absence of maternal contamination.

Eosinophil and monocyte counts were relatively constant from the 18 th to the 30 th wk of gestation. Some fetal lymphocytes are larger (but vary considerably in size) with a cytoplasm more basophilic than typical lymphocytes. The absolute counts are relatively stable. These observations disagree with those previously reported $(21,22)$.

Excluding the prenatal diagnosis of hemoglobinopathies, $\mathrm{Hb}$ abnormalities are surprisingly numerous. The geographic origin of the foreign families was about $7 \%$ from North Africa, $2 \%$ from South East Asia, and 1\% from black countries. In this population, two cases of $\mathrm{Hb} \mathrm{S}$ and one case of $\mathrm{Hb} \mathrm{E}$ were detected by IEF (5). In two children from $\beta$-thalassemic heterozygote mothers, the expression of $\mathrm{Hb} \mathrm{A}$ was lower than usual with a $\mathrm{Hb} \mathrm{A} / \mathrm{Hb} \mathrm{Fac}$ ratio below 0.5 . This method already has been used for antenatal and neonatal diagnosis of $\beta$-thalassemia $(23,24)$. If this foreign population is withdrawn, the frequency of heterozygote and homozygote fetuses for $\mathrm{Hb} F$ Sardinia is $36 \%$ for the French population. This is very close to previous data for Caucasian newborns in the United States (25) and in the Netherlands (26). Hb Bart's was detected in a group of 13 fetuses. A severe microcytosis, $(111 \mathrm{Fl}$ at $20 \mathrm{wk}$ compared to our reference value: $134 \pm 9$ ) was obvious in only one (a fetus of black African origin) of these cases. Extrapolating from reported
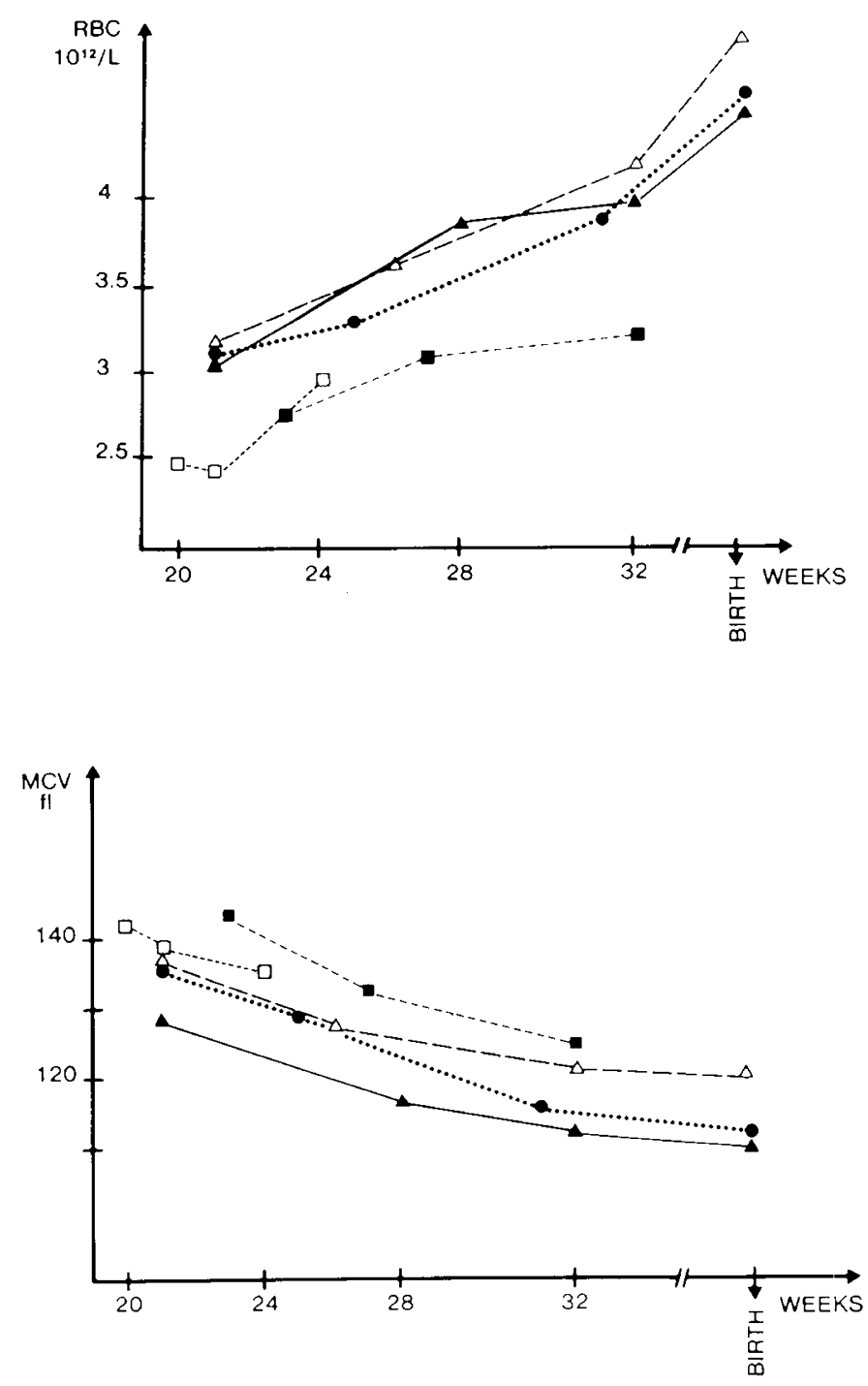

Fig. 3. Evolution of the $R B C$ and the MCV values of five fetuses each sampled three times or more during the gestation.

Table 5. Evolution of $\mathrm{Hb} \mathrm{A} / \mathrm{Hb}$ Fac ratio between 19 and 36 wk of gestation (mean $\pm S D$ )

\begin{tabular}{ccc}
$\begin{array}{c}\text { Wk of } \\
\text { gestation }\end{array}$ & $\begin{array}{c}\text { No. } \\
\text { of } \\
\text { cases }\end{array}$ & \multicolumn{1}{c}{ HbA } \\
\hline $19-21$ & 34 & $0.86 \pm 0.13$ \\
$22-24$ & 44 & $0.92 \pm 0.18$ \\
$25-27$ & 15 & $0.94 \pm 0.21$ \\
$28-30$ & 7 & $1.00 \pm 0.2$ \\
$31-36$ & 9 & $1.19 \pm 0.18$ \\
\hline
\end{tabular}


findings in black newborns (27), this latter case might be an $\alpha$ thalassemia trait. A surprising finding was the detection of three different $\gamma$ chain variants $(2.3 \%)$. Other recent studies have permitted identification of a large number of such variants, which may be more frequent than previously thought (25).

In the small number of cases in which ferritin was evaluated, no large differences were seen between individuals of varying gestational age. We did not measure ferritin values in mothers the day of the samplings. However, our normal values in the newborn range from 95 to $350 \mu \mathrm{g} /$ liter and from 5 to 30 in pregnant women at the 3rd trimester of pregnancy.

As indicated in Table 4, blood factors VIII and $\mathrm{V}$ are about $40 \%$ of the activity between 19 and 27 wk. Factors II and IX (vitamin $\mathrm{K}$ dependent) are lower (around 10\%). We did not observe any significant increase of these parameters.

These data confirm the results in prenatal diagnosis of hemophilia (which is usually performed at the 18th wk of pregnancy) and the development of hemostasis in the human fetus $(28,29)$.

In conclusion, it has been possible to establish normal hematological parameters for a large group of 163 fetuses over a 12 wk period (from the 18 th to the 30 th wk of gestation). In a few cases, we were able to obtain serial measurements of hematological values to assess fetal erythropoiesis. This work suggests that studies of selected aspects of human prenatal biology are possible without significant risk to the fetus from the 18th wk of gestation to birth. We have conducted 435 fetal blood samplings without accident by direct puncture of the umbilical cord under ultrasound. This procedure, already routinely used for prenatal diagnosis of hemophilia (31), rubella (32), and toxoplasmosis (33), could be applied to a wide range of new possibilities (34), including the study of the transplacental passage of drugs $(35$, 36 ), the administration of intrauterine therapy (37), and possibly for fetal monitoring.

Acknowledgments. The authors are grateful to Dr. J. C. Rymer for the measurements of ferritin, Y. Sole, C. Caillot for technical assistance, and A. M. Soumagnac for typing the manuscript.

\section{REFERENCES}

1. Oski FA, Naiman JL 1982 Hematologic Problems in the Newborn, 3rd ed. WB Saunders, Philadelphia, pp 4-00

2. Daffos F, Capella-Pavlovsky M, Forestier F 1983 Fetal blood sampling via the umbilical cord using a needle guided by ultrasound. Report of 66 cases. Prenat Diagn 3:271-277

3. Daffos F, Forestier F, Capella-Pavlovsky M 1983 Fetal blood sampling during the third trimester of pregnancy. Br J Obstet Gynaecol 91:118-121

4. Betke K, Marti HR, Schlicht 11959 Estimation of small percentages of fetal hemoglobin. Nature 184:1877-1878

5. Basset P. Braconnier F. Rosa J 1982 An update on electrophoresis and chromatographic methods in the diagnosis of hemoglobinopathies. J Chromatogr 227:267-304

6. Barrowcliffe TW, Tydeman MS. Curtis AD. Thomas DP, Kirkwood TBL 1983 Factor VIII standardisation. Lancet 1:62

7. Lefranc MP, Lefranc G, Farhat M, Jmour R, Boukef K, Beuzard Y, Galacteros F. Rosa J 1981 Frequency of human A $755 \mathrm{Thr}$ globin chain in a population from Tunisia. Hum Genet 59:89-91

8. Kalpaktsogrou PK. Emery JL 1965 Human bone marrow during the last 3 months of intra-uterine life. Acta Haematol 34:228-238

9. Yoffey JM, Thomas DB 1964 The development of bone marrow in the human fetus. J Anat 98:463-471

10. Nathan DG, Oski FA 1981 Haematology of Infancy and Childhood, 2nd ed. WB Saunders, Philadelphia

11. Smith MB, Cauchi NM 1982 Analysis of rates of globin synthesis in normal human fetuses, in neonates and in twins. Am J Hematol 12:121-130
12. Thomas DB, Yoffey JM 1962 Human foetal haematopoiesis I. The cellular composition of foetal blood. Br J Haematol 8:290-295

13. Yoffey JM 1970 The stem cell problem in the fetus. Fetal and neonatal erythropoiesis. Israel J Med Sci 7:825-833

14. Wintrobe MM 1961 Clinical Haematology, 5th ed. Lea \& Febiger, Philadelphia, pp 32-000

15. Cosso G, Manca M, Pirastru MG, Bullitta R, Bosisio AB, Ganazza E. Righetti PG 1982 Neonatal screening of beta-thalassemias by thin layer isoelectric focusing. Am J Hematol 13:149-158

16. Abraham EC, Reese AL, Stallings M, Abraham A, Barbutt GJ, Huisman THJ 1982 Synthesis of the minor foetal hemoglobin $F_{a c}$ in colonies of erythropoietic precursors isolated from human umbilical cord blood. Am J Hematol 12:207-214

17. Garlick RL. Shaeffer JQ, Chapman PB, Kingston RE, Mazer JS, Bunn HF 1981 Synthesis of acetylated human foetal haemoglobin. J Biol Chem 256:1727-1731

18. Peterson CM, Kalan G, Jovanovic L, Jovanovic R 1979 Use of the minor haemoglobin ratio for the determination of gestational age. Am J Obstet Gynaecol 135:85-90

19. Enzan H, Takahashi H, Kawakami M. Hamashita S, Ohkita T, Yamamoto M 1980 Light and electron microscopic observations of hepatic haematopoiesis of human fetuses II. Megakaryocytopoiesis. Acta Pathol Jap 30:937-954

20. Enzan H, Takahashi H, Kawakami M, Hamashita S, Ohkita T 1978 Light and electron microscopic observations of hepatic haematopoiesis of human fetuses. Granulopoiesis in the hepatic mesenchymal tissue. Acta Pathol Jap 28:411-426

21. Gilmour JR 1941 Normal hematopoiesis in intra-uterine and neonatal life. J Pathol Bacteriol 52:25-31

22. Playfair JHL, Wolfendale MR, Kay HEM 1963 The leucocytes of peripheral blood in the human fetus. Br J Haematol 9:336-339

23. Cao A, Pintus L, Lecca U, Olla G, Cossu P, Rosatelli C, Galanello R 1984 Control of homozygous beta-thalassemia by carrier screening and antenatal diagnosis of Sardinians. Clin Genet 26:12-22

24. Nakatsuji $\Upsilon$, Garver J, Wilson JB, Lam H, Reese AL, Nagle S, Miwa S, Huisman THJ 1983 Alpha-chain and gamma-chain abnormal haemoglobin in newborn babies. Structural and genetic aspects. Am J Hematol 14:121132

25. Huisman THJ, Reese AL, Gardiner MB, Wilson JB, Lam H, Reynolds A, Nagle S, Trowell P, Zeng YT, Huang SZ, Sukumaran PK, Miwa S, Efremov GD. Petkov G. Sciaratta GV, Sansone G 1983 The occurrence of different levels on $A \gamma$ chain and of the $A \gamma \mathrm{T}$ variant of fetal hemoglobin in newborn babies from severai countries. Am J Hematol 14:133-148

26. Bernini LF. Giordano PC, Van Lith DAF 1980 Frequency and quantitative levels of $\mathrm{T} \gamma$ chain ( $\mathrm{Hb} \mathrm{F}$ Sardinia) in the fetal hemoglobin of newborn and fetuses. Haemoglobin 4:469-482

27. Higgs DR, Pressley L. Clegg JB. Weatherall DJ, Higgs S, Carey P, Serjeant GR 1980. Detection of alpha thalassemia in negro infants. Br J Haematol 46:3948

28. Bleyer WA, Kakami N, Shepard $T 1971$ The development of haemostasis in the human fetus and newborn infant. J Pediatr 79:838-853

29. Mibashan RS, Rodeck CH, Thumpson JK, Edwards RJ, Singer JD, White JM 1979 Plasma assay of fetal factors VIIIc and IX for prenatal diagnosis of haemophilia. Lancet 1:1309-1311

30. Forestier F, Daffos F, Rainaut M, Sole Y, Amiral J 1985 Vitamin K dependent proteins in fetal hemostasis at mid trimester of pregnancy. Thromb Haemost 53:401-403

31. Forestier F, Daffos F. Capella-Pavlovsky M 1983 Premier diagnostic prenatal d'une hémophilie A par ponction directe du cordon ombilical. Presse Med 12:2462-2463

32. Daffos F, Forestier F, Grangeot-Keros L, Capella-Pavlovsky M, Lebon P, Chartier M, Pillot J 1984 Prenatal diagnosis of congenital rubella. Lancet 2:1-3

33. Desmonts G, Daffos F, Forestier F, Thuilliez P, Capella-Pavlovsky M, Chartier M 1985 Prenatal diagnosis of congenital toxoplasmosis. Lancet 1:500-503

34. Alter PB 1984 Advances in the prenatal diagnosis of haematological diseases. Blood 64:329-340

35. Forestier F, Daffos F. Capella-Pavlovsky M 1984 Low molecular weight heparin (PK 10169) does not cross the placenta during the second trimester of pregnancy. Study by direct foetal blood sampling under ultrasound. Thromb Res 34:557-560

36. Forestier F, Daffos F, Rainaut M 1985 Pre-eclampsia and prostaglandins Lancet 1:1268

37. Daffos F, Forestier F, Muller JY, Reznikoff-Etievant MF, Habibi B, CapellaPavlovsky M, Maigret P, Kaplan C 1984 Prenatal treatment of alloimmune thrombocytopenia. Lancet 2:632 